\title{
Robust
}

\author{
Research Business and Economics Studies
}

journal homepage: http://ejournal.iainkendari.ac.id/robust

\section{Pemanfaatan Media Sosial Dan Pembiayaan Bank Umum Syariah Dalam Pengembangan Usaha Mikro Dan Kecil Di Kecamatan Puuwatu Kota Kendari}

\author{
${ }^{1}$ Nurjannah, ${ }^{2}$ Alfian Toar, ${ }^{2}$ Beti Mulu, ${ }^{3}$ Imran, ${ }^{4}$ Muhammad Rusydi Navri \\ 1,2,3,4,Fakultas Ekonomi dan Bisnis Islam-IAIN KENDARI \\ Email: 1urjannahnur76@gmail.com \& nurjannah@iainkendari.ac.id
}

\begin{tabular}{|c|c|}
\hline ARTICLE INFO & A B S T R A C T \\
\hline Keywords: & Salah satu faktor pendukung untuk meningkatkan kinerja \\
\hline Pemanfaatan Media Sosial, & UMKM adalah penggunaan teknologi informasi. \\
\hline Pembiayaan Bank Umum & Tercapainya kinerja yang positif tentunya dengan \\
\hline Syariah, Pengembangan Usaha, & meningkatkan daya saing UMKM. Penggunaan teknologi \\
\hline Usaha Mikro dan Kecil & informasi akan mampu meningkatkan transformasi bisnis, \\
\hline & ketepatan, dan efisiensi pertukaran informasi. Hasil \\
\hline & Penelitian ini menunjukkan bahwa dari 10 sampel Usaha \\
\hline Article History: & Mikro dan Kecil ada $90 \%$ yang telah memanfaatkan media \\
\hline Received 06 January 2021 & sosial sebagai sarana pemasaran produk. Media sosial yang \\
\hline $1^{\text {st }}$ Received in revised form 28 February & dominan digunakan oleh pelaku Usaha Mikro dan Kecil di \\
\hline 2021 & Kecamatan Puuwatu Kota Kendari adalah media sosial \\
\hline $2^{\text {nd }}$ Received in revised form 19 March & facebook. Media sosial telah memberikan banyak \\
\hline 2021 & kontribusi terhadap pelaku Usaha Mikro dan Kecil di \\
\hline $3^{\text {rd }}$ Received in revised form 25 April & Kecamatan Puuwatu Kota Kendari yaitu, meningkatkan \\
\hline 2021 & penjualan produk, membangun kesadaran merek, serta \\
\hline Available online 30 April 2020 & memudahkan interaksi secara online dengan konsumen. \\
\hline & Pembiayaan bank umum syariah masih minim \\
\hline & dimanfaatkan oleh pelaku Usaha Mikro dan Kecil di \\
\hline & Kecamatan Puuwatu Kota Kendari. Dari 10 sampel Usaha \\
\hline & Mikro dan Kecil hanya ada 1 pelaku Usaha Mikro dan Kecil \\
\hline & yang memanfaatkan pembiayaan di bank umum syariah \\
\hline & yaitu dalam bentuk akad mudharabah. Disamping itu \\
\hline & mayoritas dari pelaku Usaha Mikro dan Kecil terus \\
\hline http://dx.doi.org/10.31332/robust.vli1.2666 & memutar keuntungan penjualannya sehingga sangat minim \\
\hline (C) 2021 Robust. All rights & pelaku Usaha Mikro dan Kecil yang menggunakan jasa \\
\hline reserved & bank umum syariah dalam menyimpan modal usahanya. \\
\hline
\end{tabular}




\section{Pendahuluan}

Salah satu faktor pendukung untuk meningkatkan kinerja UMKM adalah penggunaan teknologi informasi. Tercapainya kinerja yang positif tentunya dengan meningkatkan daya saing UMKM. Penggunaan teknologi informasi akan mampu meningkatkan transformasi bisnis, ketepatan, dan efisiensi pertukaran informasi. Khristianto (2012) menambahkan jika teknologi informasi pada saat ini akan memperluas jaringan pemasaran dan memperluas marketshare. Pada era digital ini, teknologi informasi menjadi salah satu faktor penting dalam pengembangan UMKM di Indonesia, khususnya di Sulawesi Tenggara, tak terkecuali di Kota Kendari, berikut data jumlah pedagang menurut Kecamatan di Kota Kendari tahun 2019 :

Tabel 1.

Jumlah Pedagang Menurut Kecamatan di Kota Kendari, 2019

\begin{tabular}{|c|c|c|c|c|}
\hline NO & Kecamatan & $\begin{array}{l}\text { Pedagang } \\
\text { Besar }\end{array}$ & $\begin{array}{l}\text { Pedagang } \\
\text { Menengah }\end{array}$ & $\begin{array}{c}\text { Pedagang } \\
\text { Kecil }\end{array}$ \\
\hline 1 & Mandonga & 32 & 112 & 241 \\
\hline 2 & Baruga & 15 & 191 & 172 \\
\hline 3 & Puuwatu & 8 & 98 & 166 \\
\hline 4 & Kadia & 30 & 215 & 328 \\
\hline 5 & Wua-wua & 19 & 167 & 254 \\
\hline 6 & Poasia & 15 & 143 & 242 \\
\hline 7 & Abeli & 2 & 22 & 62 \\
\hline 8 & Kambu & 8 & 96 & 191 \\
\hline 9 & Nambo & 2 & 13 & 36 \\
\hline 10 & Kendari & 9 & 119 & 277 \\
\hline 11 & Kendari Barat & 11 & 105 & 254 \\
\hline Total & & 151 & 1.281 & 2.223 \\
\hline
\end{tabular}

Sumber : Dinas Perdagangan, Koperasi dan UMKM Kota Kendari

Terlebih hari ini tidak hanya perusahaan besar yang menggunakan internet sebagai bagian pemasaran lain dari perusahaannya usaha-usaha kecil juga menggunakannya bahkan pada tahun 2019 nilai transaksi melalui bisnis online tercatat mencapai angka 265,07 triliun dengan jumlah pengguna internet sebesar 107,2 juta pengguna tumbuh 12,6\% dibandingkan tahun 2018 (Kontan.co.id, 11 Februari 2020). 
Salah satu faktor pendukung untuk meningkatkan kinerja UMKM adalah penggunaan teknologi informasi. Tercapainya kinerja yang positif tentunya dengan meningkatkan daya saing UMKM. Penggunaan teknologi informasi akan mampu meningkatkan transformasi bisnis, ketepatan, dan efisiensi pertukaran informasi.

Efendy Zain (2010) menyatakan bahwa Industri perbankan syariah tentu tidak lepas dari pembiayaan dalam menopang ekonomi nasional terutama pada peningkatan pembiayaan di sektor UMKM yang saat ini belum diikuti pemahaman serta pengetahuan sebagian pelaku UMKM terhadap sistem operasional perbankan syariah, mekanisme dan cara mengakses skim-skim pembiayaan untuk UMKM pada perbankan syariah. Hal ini dapat mempengaruhi tingkat aksesibilitas UMKM dalam memperoleh pembiayaan untuk menjalankan kegiatan usahanya dari perbankan syariah yang saat ini sedang tumbuh pesat.

Peranan perbankan Syariah dalam pengembangan sektor riil dapat dilihat dari skema yang dikembangkan dalam pembiayaan bank umum syariah, selain dalam kontribusi nyata yang disumbangkan oleh bank umum syariah melalui tugasnya sebagai lembaga intermediasi keuangan. Dilihat dari skema pembiayaan yang dikembangkan, bank umum Syariah hanya menyalurkan pembiayaannya untuk sektor riil. Dinamika bisnis yang terjadi pada sektor riil akan terefleksi langsung pada kegiatan perbankan Syariah.

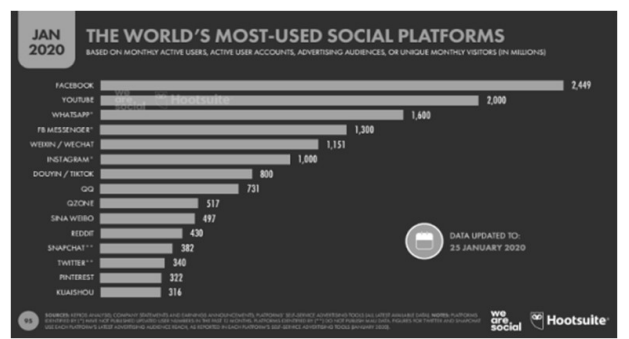

Sumber : hootsuite.com Social Media Management Platform

Dari data di atas secara peringkat Facebook menjadi sosial media yang paling populer di dunia dengan 2,449 milyar akun. Dari data di atas menggambarkan bahwa bagaimana sosial media saat ini menjadi layanan yang cukup dominan diminati di dunia maya. Mengingat visi internet pada permulaaanya adalah untuk menghubungkan satu dengan lainnya (teknoia.com, 2020). 
Nurjannah, Dkk./Robust-Research Business and Economics Studies, Volume 1 (No.1 2021)

\section{Kajian Pustaka}

Istilah pemanfaatan berasal dari kata dasar manfaat yang berarti faedah, yang mendapat imbuhan pe-an yang berarti proses atau perbuatan memanfaatkan (Poerwadarminto, 2002).Menurut (Cindy Paramitha Rizal, 2012) Media sosial (Social Media) adalah media yang didesain untuk memudahkan interaksi sosial yang bersifat interaktif. Media sosial berbasis pada teknologi internet yang mengubah pola penyebaran informasi yang sebelumnya bersifat satu ke banyak audiens, banyak audiens ke banyak audiens.

Media sosial menurut Kaplan and Haenlein (2010) merupakan sekelompok aplikasi yang berbasiskan pada internet dan dibangun berdasarkan kerangka pikiran ideologi dan teknologi dari platform Web 2.0, medium ini dapat menghubungkan individu dengan individu untuk sharing dan berkumpul secara online, Web 2.0 merupakan suatu platform dasar terbentuknya media sosial, platform ini menyediakan kemudahan bagi penggunanya untuk berkolaborasi secara online dan berbagi (sharing) Media sosial seperti Facebook, Twitter, Youtube, Instagram, saat ini digunakan untuk menyebarluaskan informasi secara cepat, viral, dan menyebar kepada pengguna internet dalam jumlah yang besar.

Menurut Zarella (2010) media sosial adalah sebuah paradigma baru dalam konteks industri pemasaran yang paling baik dijelaskan dalam konteks paradigma industri media tradisional. Media tradisional, semisal televisi, surat kabar, radio, dan majalah adalah teknologi monolog dan statis. Penerbit majalah yang merupakan organisasi besar yang mendistribusikan konten yang mahal kepada konsumen, dan pemasang iklan membayar untuk menyisipkan iklan mereka di dalam konten tersebut. Ketika kita duduk asyik menonton program televisi favorit, tetapi tiba-tiba keasyikan dan terpotong oleh jeda iklan. jika tidak setuju dengan sesuatu yang kita baca di surat kabar, tentu kita tidak bisa langsung memprotes redakturnya.

Daniel Iman, dkk. (2005) menyatakan bahwa berbeda halnya perkembangan teknologi-teknologi website baru memudahkan semua orang untuk membuat dan yang terpenting menyebarluaskan konten mereka sendiri. Post di blog, tweet, atau video di Youtube dapat diproduksi dan dilihat oleh jutaan orang secara gratis. Pemasang iklan tidak harus membayar banyak uang kepada penerbit atau distributor untuk memasang iklannya. Sekarang, pemasang iklan dapat membuat konten sendiri yang menarik dan dilihat banyak orang. Definisi Facebook Marketing yang dikutip dari Zainal Muttaqin (2011) adalah melakukan aktivitas pemasaran menggunakan semua fasilitas yang disediakan oleh Facebook dengan tujuan meningkatkan penjualan (sales) dan menjalin komunikasi yang lebih lama dan akrab dengan pelanggan (customer relationship). 
Menurut Ginting (2012), Facebook diartikan sebagai mesin yang sangat pintar, canggih, serba komplit, namun justru sangat user friendly. Dari segi teknis, Facebook juga bersifat open source sehingga pengguna bisa menambahkan sendiri aplikasi yang disukai. Sedangkan dari segi sosial, Facebook bisa dikatakan sebagai identitas di dunia maya.

Menurut Nisrina (2015) Instagram adalah sebuah aplikasi yang digunakan untuk membagikan foto dan video. Instagram sendiri merupakan bagian dari Facebook, setelah Mark Zuckenberg mengakuisisinya pada tahun 2012. Dan karena merupakan bagian dari Facebook, memungkinkan teman di Facebook bisa mem-follow akun instagram kita. Makin populernya Instagram sebagai aplikasi yang digunakan untuk membagi foto, membuat banyak penggunanya yang mulai melakukan bisnis online dengan mempromosikan produk-produknya melalui Instagram.Menurut Bambang Dwi Atmoko (2012), Media Sosial sebagai aplikasi yang diminati banyak pengguna, Instagram menjadi media sosial yang banyak sekali peluang untuk berbisnis bagi para penggunanya, bisa dimanfaatkan sebagai media komunikasi pemasaran, melalui share foto-foto produk, dan tentunya memiliki banyak followers. Instagram memudahkan konsumen untuk melihat produk yang dijual dan dapat langsung memberi komentar di bawah foto yang diminati.

Mohamed Trio dan Debbey Arisandi (2018) menyatakan bahwa, pelaku Usaha Mikro Kecil Menengah (UMKM) harus mampu bersaing di pasar internasional agar tak tertindas. Apalagi, di era persaingan ini, pelaku UMKM seharusnya melek akan teknologi informasi (TI) agar dapat memudahkan memasarkan produk hingga ke luar negeri. Tercatat, jumlah UMKM di Indonesia cukup banyak, sekitar 50 juta pelaku UMKM. Dalam era digital saat ini, pelaku UMKM akan membutuhkan teknologi informasi yang tepat untuk bisa tumbuh berkembang dan bersaing di era digital saat ini. Pelaku UMKM menemui kesulitan untuk mendapatkan solusi teknologi informasi yang tepat karena pelaku UMKM tidak memiliki staf khusus yang ahli dalam bidang teknologi informasi yang dinamis. Kendala lain, yakni banyaknya ragam produk teknologi, membuat pelaku UMKM bingung memilih solusi yang pas. Oleh sebab itu para pelaku UMKM membutuhkan panduan dalam memilih teknologi informasi yang tepat sesuai jenis usaha dan kebutuhannya. Menurut Stelzner dikutip dari Purwana (2017) media sosial berpotensi untuk membantu pelaku UMKM dalam memasarkan produknya. Aplikasi media sosial tersedia mulai dari pesan instan hingga situs jejaring sosial yang menawarkan pengguna untuk berinteraksi, berhubungan, dan berkomunikasi satu sama lain.

Menurut Veithzal Rival dan Arviyan Arifin (2010) dalam bukunya Islamic Banking menyatakan, bahwa pembiyaan adalah penyediaan uang atau tagihan yang dapat dipersamakan dengan itu, berdasarkan persetujuan atau kesepakatan pinjam meminjam antara bank dan lembaga keuangan lainnya dengan pihak 
lain yang mewajibkan pihak peminjam untuk melunasi utangnya setelah jangka waktu tertentu dengan imbalan atau bagi hasil.

Sedangkan menurut Undang-Undang Perbankan No. 10 Tahun 1998, pembiayaan adalah penyediaan uang atau tagihan yang dapat dipersamakan dengan itu, berdasarkan persetujuan atau kesepakatan antara bank dan pihak lain yang dibiayai untuk mengembalikan uang atau tagihan tersebut setelah jangka waktu tertentu dengan imbalan atau bagi hasil.

Dalam perekonomian Indonesia UMKM merupakan kelompok usaha yang memiliki jumlah paling besar dan terbukti tahan terhadap berbagai macam goncangan krisis ekonomi. Kriteria usaha yang termasuk dalam UMKM telah diatur dalam payung hukum. Menurut Undang-Undang Republik Indonesia Nomor 20 Tahun 2008 tentang Usaha Mikro, Kecil, dan Menengah (UMKM) bahwa sesuai dengan amanat Ketetapan Majelis Permusyawaratan Rakyat Republik Indonesia Nomor XVI/MPR-RI/1998 tentang politik ekonomi dalam rangka demokrasi ekonomi, UMKM perlu diberdayakan sebagai bagian integral ekonomi rakyat yang mempunyai kedudukan, peran, dan potensi strategis untuk mewujudkan struktur perekonomian nasional yang makin seimbang, berkembang, dan berkeadilan (bi.go.id, 2020)

Wulan Ayodya (2020) menyatakan bahwa, sesuai dengan Undang-Undang Nomor 20 Tahun 2008 tentang Usaha Mikro, Kecil, dan Menengah (UMKM) yaitu :

\section{1) Usaha Mikro}

Adalah usaha produktif milik orang perorangan dan / atau badan usaha perorangan yang memenuhi kriteria Usaha Mikro sebagaimana diatur dalam Undang-Undang tersebut.

\section{2) Usaha Kecil}

Adalah usaha ekonomi produktif yang berdiri sendiri, yang dilakukan oleh orang perorangan atau badan usaha yang bukan merupakan anak perusahaan atau bukan cabang perusahaan yang dimiliki, dikuasai, atau menjadi bagian baik langsung maupun tidak langsung dari usaha menengah atau usaha besar yang memenuhi kriteria Usaha Kecil sebagaimana dimaksud dalam Undang-Undang tersebut.

\section{3) Usaha Menengah}

Adalah usaha ekonomi produktif yang berdiri sendiri, yang dilakukan oleh orang per orangan atau badan usaha yang bukan merupakan anak perusahaan atau cabang perusahaan yang dimiliki, dikuasai, atau menjadi bagian baik langsung maupun tidak langsung dengan Usaha Kecil atau usaha besar dengan jumlah kekayaan bersih atau hasil penjualan tahunan sebagaimana diatur dalam Undang-Undang tersebut 
Menurut Tulus (2010), UMKM yang terus mengalami peningkatan dan perkembangan yang baik dapat dilihat dari beberapa ciri sebagi berikut:
a. Tenaga kerja yang terampil
b. Produk UMKM yang variatif
c. Akses UMKM terhadap pasar semakin luas
d. Teknologi yang semakin canggih/modern
e. Omset dan profitabilitas meningkat
f. UMKM yang akan bisa membuat produk-produk yang kompetitif yang berarti juga UMKM yang bisa bertahan terus dan bahkan berkembang pesat.

\section{Metode Penelitian}

Gunawan Imam (2013) menyatakan bahwa "Jenis penelitian yang digunakan dalam penelitian ini adalah penelitian kualitatif dengan pendekatan deskriptif, yaitu jenis penelitian yang temuan-temuannya tidak diperoleh melalui prosedur statistik atau bentuk hitungan lainnya" (h.3). Akan tetapi menurut (Lexy J. Moleong, 2002) data-datanya berupa kata-kata yang berasal dari wawancara, catatan laporan, dokumen lainnya atau penelitian yang di dalamnya mengutamakan pendeskripsian secara analisis tentang suatu peristiwa untuk memperoleh makna yang mendalam dari hakekat proses tersebut.

Penelitian ini dilaksanakan pada 10 jenis UMK yang ada di Kecamatan Puuwatu Kota Kendari antara lain : Rumah Tenun Mahkota, Gudang Telur, Sifa Bakery, TATOP Kendari, Kedai Pempek Cinta, A3 Store, Durian Online, Bakso Barokah, RM. Pangkep dan Deal Management. Alasan pemilihan tempat ini didasarkan atas berbagai pertimbangan. Pertama, karena saya ingin mengetahui seberapa besar dampak pemanfaatan media sosial oleh pelaku UMK di Kecamatan Puuwatu Kota Kendari dalam memasarkan produknya. Kemudian yang selanjutnya, di Kecamatan ini terdapat beberapa UMK yang menghasilkan produk khas Sulawesi Tenggara.Teknik pengumpulan data yang digunakan pada penelitian lapangan (field research) yaitu penulis mengumpulkan data dengan melakukan penelitian langsung pada obyek yang diteliti. Namun ditengah situasi pandemi Covid-19 ini untuk melakukan penelitian sangat terbatas karena adanya peraturan Social Distancing sehingga sebagian pelaku UMK meminta untuk melakukan penelitian secara online, dengan itu penelitian ini dilakukan dengan 2 cara yaitu pengumpulan data secara langsung ke lokasi Usaha Mikro dan Kecil yang ada di Kecamatan Puuwatu Kota Kendari, dan pengumpulan data melalui via 
Whatsapp / Telephone dengan menggunakan berbagai instrumen yaitu Observasi, Wawancara, dan Studi Dokumen.

Analisis data menurut Bogdan Sugiono (2005) adalah proses mencari dan menyusun data secara sistematis yang dipeoleh dari hasil wawancara, catatan lapangan dan dokumentasi dengan cara mengorganisasikan data kedalam kategori, menjabarkan kedalam unit-unit melakukan sintesa, menyusun dengan pola, memilih mana yang penting dan yang akan dipelajari dan membuat kesimpulan sehingga mudah dipahami oleh diri sendiri maupun orang lain.Menurut Afiah Faisal (2001) Penelitian kualitatif perlu ditetapkan keabsahan data untuk menghindari adanya data yang bias atau tidak valid. Hal ini dimaksudkan agar dapat menghindari jawaban dari responden yang tidak jujur. Pengujian keabsahan data dalam penelitian ini menggunakan teknik triangulasi yaitu: Teknik pengujian keabsahan data dengan memanfaatkan sesuatu yang lain di luar data yang ada untuk kepentingan pengujian keabsahan data atau sebagai bahan pembanding terhadap data yang ada. Pengujian keabsahan data yang digunakan dalam penelitian ini ada dua macam yaitu Triangulasi Sumber dan Triangulasi Teknik.

\section{Hasil dan Pembahasan}

Dalam proses pengambilan data, peneliti mewawancarai UMK untuk mengetahui bagaimana pemanfaatan media sosial dalam mengembangkan bisnisnya baik dari segi pemasarannya, bagaimana berkomunikasi dengan konsumen, bagaimana media sosial berkontribusi terhadap UMK, serta ingin mengetahui media sosial apa yang dominan digunakan oleh pelaku UMK di Kecamatan Puuwatu Kota Kendari.

Pada penelitian ini terdapat 10 sampel UMK yang bergerak pada macam-macam bidang yaitu diantaranya, kuliner, kerajinan, konveksi, jasa dan lain lain. Namun dari UMK tersebut hanya 9 UMK yang memanfaatkan media sosial untuk pemasaran produknya. Dari 9 responden tersebut adalah UMK yang sudah menggunakan dan memanfaatkan media sosial untuk memasarkan produk-produknya. Dari hasil wawancara tersebut seluruhnya dapat diolah menjadi data yang berguna bagi kelanjutan penelitian ini. 
Tabel 2.

Data UMK Kecamatan Puuwatu Kota Kendari

\begin{tabular}{cllll}
\hline NO & Pelaku UMK & Nama Usaha & $\begin{array}{c}\text { Kriteria } \\
\text { Usaha }\end{array}$ & Penggunaan Medsos \\
\hline 1 & Rahmawaty Indra & RM. Pangkep & Kecil & Belum \\
\hline 2 & Samsudi & TATOP Kendari & Mikro & Facebook \\
\hline 3 & Marwan Abdul & Durian Online & Kecil & Facebook \\
\hline 4 & Ahmad Rusyaid & A3 Store & Mikro & Facebook \\
\hline 5 & Rusdi & Sifa Bakeri & Mikro & Facebook \\
\hline 6 & Hj. Endang & Rumah Tenun & Kecil & Facebook \& Instagram \\
\hline 7 & Baitul Rahman & Gudang Telur & Kecil & Facebook \& Instagram \\
\hline 8 & Rahmat & Deal Management & Kecil & Facebook \& Instagram \\
\hline 9 & Winda Bahar & Pempek Cinta & Mikro & Facebook \& Instagram \\
\hline 10 & Indri Asmarani & Bakso Barokah & Mikro & Facebook \& Instagram \\
\hline
\end{tabular}

*Sumber : Wawancara pelaku usaha mikro dan kecil di Kecamatan Puuwatu Kota Kendari

Kecamatan Puuwatu Kota Kendari terletak di Provinsi Sulawesi Tenggara, yang terdiri dari 6 kelurahan dengan luas wilayah sebagai berikut :

Tabel 3.

Luas Wilayah Kecamatan Puuwatu Menurut Kelurahan

\begin{tabular}{clcc}
\hline NO & Kelurahan & $\begin{array}{c}\text { Luas } \\
(\text { Km } 2 / \mathbf{s q . k m})\end{array}$ & $\begin{array}{c}\text { Area Presentase } \\
\text { Kecamatan Puuwatu }\end{array}$ \\
\hline 1 & Puuwatu & 11,08 & 25,47 \\
\hline 2 & Watulondo & 8,43 & 19,37 \\
\hline 3 & Punggolaka & 4,52 & 10,39 \\
\hline 4 & Tobuuha & 1,92 & 4,41 \\
\hline 5 & Lalodati & 8,71 & 20,02 \\
\hline 6 & Abeli Dalam & 8,85 & 20,34 \\
\hline & Kecamatan Puuwatu & $\mathbf{4 3 , 5 1}$ & $\mathbf{1 0 0 , 0 0}$ \\
\hline
\end{tabular}

${ }^{\star}$ Sumber : Pendataan Potensi Desa (PODES), BPS/ Village Potential Ddata Collecting,BPS 
Nurjannah, Dkk./Robust-Research Business and Economics Studies, Volume 1 (No.1 2021)

\section{UMK Kecamatan Puuwatu Kota Kendari}

UMK di Kecamatan Puuwatu Kota Kendari berkembang dengan pesat dengan adanya media sosial sebagai perantara yang dapat mengenalkan produk-produk pelaku UMK. Sehingga para pelaku UMK sangat mudah mempromosikan usahanya dan menjangkau banyak pelanggan. Meskipun pada situasi pandemi Covid-19 ini, dimana banyak usaha yang mengalami penurunan penjualan akibat adanya kebijakan Social Distancing dan Stay at home, namun para pelaku UMK di Kecamatan Puuwatu Kota Kendari tetap mendapatkan keuntungan dan merasa sangat terbantu dengan adanya media sosial yang dapat menjadi penghubung antara pelaku UMK dan masyarakat.

Di Kecamatan Puuwatu Kota Kendari banyak UMK yang berkembang disana baik yang bergerak dalam bidang kuliner, jasa, maupun busana. Kebanyakan dari mereka merupakan usaha rumahan yang dilakukan sendiri ataupun usaha keluarga. Namun ada beberapa dari mereka yang sistem pemasarannya masih menggunakan sistem tradisional yaitu memasarkan dengan menjual langsung ke pembeli atau dititipkan ke warung-warung terdekat.

Dari beberapa pelaku UMK di Kecamatan Puuwatu Kota Kendari menyatakan bahwa penjualan media sosial sangat efektif dalam memperkenalkan produk secara luas ke masyarakat, membangun kesadaran merek, dan meningkatkan penjualan.

\section{Pemanfaatan Media Sosial}

Teknologi saat ini terus berkembang dan manfaat penggunaan internet terasa bagi para pemakainya. Beberapa orang merasa ketergantungan dengan berkembangnya internet. Termasuk aktivitas Usaha Mikro dan Kecil (UMK) dalam memanfaatkan teknologi informasi untuk menjalankan usahanya.

Semakin banyaknya pesaing menjadi pertimbangan bagi pelaku usaha untuk melakukan inovasi dalam memenangkan persaingan tersebut. Strategi komunikasi pemasaran yang tepat digunakan untuk bisa meraih pangsa pasar yang dituju sehingga dapat meningkatkan penjualan (Pradiani, 2017).

Penggunaan media sosial bukan hanya digunakan oleh para anak-anak muda, sekarang banyak orang dewasa yang banyak juga menggunakan media sosial. Manfaat yang dirasakan pelaku UMK di Kecamatan Puuwatu Kota Kendari yaitu dengan memanfaatkan media sosial dapat meminimalisir biaya yang digunakan untuk promosi. Jangkauan yang sangat luas dapat menembus pasar yang luas pula, bukan hanya sekedar di daerah sendiri namun juga dapat menembus pasar nasional bahkan internasional. Selain jangkauan yang sangat luas penggunaan media sosial juga bergerak dengan cepat, melihat penggunaan media sosial pada saat ini yang sangat tinggi khususnya pada situasi Covid-19 ini. 
Tabel 5.

Pemanfaatan Media Sosial oleh UMK

\begin{tabular}{cc}
\hline Jenis Media Sosial & n (\%) \\
\hline Facebook & $10(90 \%)$ \\
\hline Instagram & $5(50 \%)$
\end{tabular}

${ }^{\star}$ Sumber : Wawancara pelaku usaha mikro dan kecil di Kecamatan Puuwatu Kota Kendari.

\section{Kontribusi Media Sosial Terhadap Pelaku UMK di Kecamatan Puuwatu Kota Kendari}

Pemanfaatan media sosial berdampak positif bagi pelaku UMK di Kecamatan Puuwatu Kota Kendari. Selain meningkatkan penjualan produk pemanfaatan media sosial juga dapat membangun kesadaran merek serta dapat berinteraksi secara online dengan konsumen.

\section{a. Meningkatkan Penjualan Produk}

Memanfaatkan media sosial dalam pengembangan UMK bagi pelaku UMK di Kecamatan Puuwatu Kota Kendari dapat memudahkan promosi usaha ke masyarakat serta dapat menghemat biaya promosi bahkan biaya operasional usaha. Dengan itu pendapatan UMK semakin meningkat dibandingkan menjual produk secara tradisional.

Tabel 6.

Presentase Penjualan Secara Tradisional dan Media Sosial

\begin{tabular}{|c|c|c|c|c|}
\hline \multirow{2}{*}{ NO } & \multirow{2}{*}{ Nama Usaha } & Presentase $\quad$ Penjualan & Presentase & Penjualan \\
\hline & & Secara Tradisional & \multicolumn{2}{|l|}{ Media Sosial } \\
\hline 1 & Rumah Tenun Mahkota & $30 \%$ & $70 \%$ & \\
\hline 2 & TATOP Kendari & $20 \%$ & $80 \%$ & \\
\hline 3 & Gudang Telur & $30 \%$ & $70 \%$ & \\
\hline 4 & Durian Online & $30 \%$ & $70 \%$ & \\
\hline 5 & Deal Management & $70 \%$ & $30 \%$ & \\
\hline 6 & Pempek Cinta & $40 \%$ & $60 \%$ & \\
\hline 7 & A3 Store & $20 \%$ & $80 \%$ & \\
\hline 8 & Bakso Barokah & $50 \%$ & $50 \%$ & \\
\hline 9 & RM. Pangkep & - & - & \\
\hline \multirow[t]{2}{*}{10} & Sifa Bakeri & $60 \%$ & $40 \%$ & \\
\hline & RATA-RATA & $38,89 \%$ & $61,11 \%$ & \\
\hline
\end{tabular}

*Sumber : Wawancara pelaku usaha mikro dan kecil di Kecamatan Puuwatu Kota Kendari 
Nurjannah, Dkk./Robust-Research Business and Economics Studies, Volume 1 (No.1 2021)

Tabel diatas merupakan hasil wawancara yang telah dilakukan yang menunjukkan bahwa dari 10 sampel UMK di Kecamatan Puuwatu Kota Kendari mayoritas mendapatkan keuntungan yang lebih besar dari penjualan secara online dibandingkan penjualan secara tradisional. Dengan nilai rata-rata $38,89 \%$ keuntungan dari penjualan secara tradisional dan $61,11 \%$ keuntungan dari penjualan melalui media sosial.

Tabel 7.

Keuntungan Penjualan Secara Tradisional dan Media Sosial Perbulan

\begin{tabular}{|c|c|c|c|c|}
\hline NO & Nama Usaha & $\begin{array}{l}\text { Penjualan } \\
\text { tradisional } \\
\text { perbulan }\end{array}$ & $\begin{array}{l}\text { Penjualan media } \\
\text { sosial perbulan }\end{array}$ & $\begin{array}{l}\text { Total pendapatan } \\
\text { perbulan }\end{array}$ \\
\hline 1 & $\begin{array}{l}\text { Rumah Tenun } \\
\text { Mahkota }\end{array}$ & Rp. 9.000 .000 & Rp. 21.000.000 & Rp. 30.000 .000 \\
\hline 2 & Durian Online & Rp. 5.700.000 & Rp. 13.300 .000 & Rp. 19.000.000 \\
\hline 3 & Gudang Telur & Rp. 12.000 .000 & Rp. 28.000 .000 & Rp. 40.000 .000 \\
\hline 4 & Bakso Barokah & Rp. 1.250 .000 & Rp. 1.250 .000 & Rp. 2.500 .000 \\
\hline 5 & Pempek Cinta & Rp. 4.000 .000 & Rp. 6.000 .000 & Rp. 10.000 .000 \\
\hline 6 & Sifa Bakery & Rp. 1.800 .000 & Rp. 1.200 .000 & Rp. 3.000 .000 \\
\hline
\end{tabular}

${ }^{\star}$ Sumber : Wawancara pelaku usaha mikro dan kecil di Kecamatan Puuwatu Kota Kendari

Tabel diatas merupakan hasil wawancara yang telah dilakukan yang menunjukkan bahwa 6 sampel UMK di Kecamatan Puuwatu Kota Kendari mengalami kenaikan penjulan media sosial yang lebih besar dari penjualan secara tradisional. 
Nurjannah, Dkk./Robust-Research Business and Economics Studies, Volume 1 (No.1 2021)

Tabel 8.

Perbandingan Penjualan Perbulan Tahun 2018, 2019, dan 2020

\begin{tabular}{|c|c|c|c|c|}
\hline NO & Nama Usaha & $\begin{array}{l}\text { Penjualan } \\
\text { Perbulan Tahun } \\
2018\end{array}$ & $\begin{array}{l}\text { Penjualan } \\
\text { Perbulan Tahun } \\
2019\end{array}$ & $\begin{array}{l}\text { Penjualan } \\
\text { Perbulan } \\
\text { Tahun } 2020\end{array}$ \\
\hline 1 & $\begin{array}{l}\text { Rumah Tenun } \\
\text { Mahkota }\end{array}$ & Rp. 75.000 .000 & Rp. 90.000 .000 & Rp. 30.000 .000 \\
\hline 2 & Durian Online & Rp. 25.000 .000 & Rp. 25.000 .000 & Rp. 19.000 .000 \\
\hline 3 & Gudang Telur & Rp. 30.000 .000 & Rp. 30.000 .000 & Rp. 40.000 .000 \\
\hline 4 & Bakso Barokah & Rp. 3.500 .000 & Rp. 4.000 .000 & Rp. 2.500 .000 \\
\hline 5 & Pempek Cinta & Rp. 15.000 .000 & Rp. 15.000 .000 & Rp. 10.000 .000 \\
\hline 6 & Sifa Bakery & Rp. 6.000 .000 & Rp. 6.000 .000 & Rp. 3.000 .000 \\
\hline
\end{tabular}

${ }^{\star}$ Sumber : Wawancara pelaku usaha mikro dan kecil di Kecamatan Puuwatu Kota Kendari

Tabel 8.

Jumlah Pembeli Yang Didapatkan Dari Media Sosial Perbulan Dan Harga Satuan Produk

\begin{tabular}{llll}
\hline NO & \multicolumn{1}{c}{ Nama Usaha } & $\begin{array}{c}\text { Jumlah Pembeli } \\
\text { dari media sosial } \\
\text { perbulan }\end{array}$ & \multicolumn{1}{c}{ Harga Satuan Produk } \\
\hline 1 & Rumah Tenun Mahkota & 50 orang & Rp.400.000 - Rp.4.000.000 \\
\hline 2 & Durian Online & 450 orang & Rp.10.000 - Rp.100.000 \\
\hline 3 & Gudang Telur & 3000 rak & Rp.45.000 - Rp.50.000 \\
\hline 4 & Bakso Barokah & 300 orang & Rp.13.000 - Rp.22.000 \\
\hline 6 & Pempek Cinta & 900 orang & Rp.10.000 - Rp.30.000 \\
\hline 7 & Tifa Bakery & 15 orang & Rp.5000 - Rp.7000 \\
\hline 8 & A3 Store & 100 orang & Rp.15.000 - Rp.20.000 \\
\hline 9 & Deal Managemen & 390 orang & Rp.22.000 - Rp.65.000 \\
\hline
\end{tabular}

${ }^{\star}$ Sumber : Wawancara pelaku usaha mikro dan kecil di Kecamatan Puuwatu Kota Kendari 
Nurjannah, Dkk./Robust-Research Business and Economics Studies, Volume 1 (No.1 2021)

\section{b. Membangun Kesadaran Merek (Brand Awareness)}

Memanfaatkan media sosial dalam pengembangan UMK juga dapat meningkatkan citra usaha. Pelaku UMK dapat mempromosikan usahanya dengan mudah dengan secara rutin mengunggah foto ataupun video produk yang dijual. Pelaku UMK juga harus membuat unggahan foto ataupun video produk yang menarik sehingga dapat menarik masyarakat untuk melihat, mengunjungi, dan membeli produk yang dijual. Memanfaatkan media sosial sebagai sarana pemasaran, akan memungkinkan UMK untuk memperluas jaringan customer sehingga sangat berpeluang akan lebih banyak orang yang akan melihat produk-produk yang di jual, tidak hanya orang disekitar daerah saja bahkan bisa dilihat oleh seluruh masyarakat indonesia bahkan dunia.UMK sebagai kekuatan ekonomi masyarakat, harus dapat melakukan pemasaran secara gerilya. Media Sosial dengan segala kelebihan dan fiturnya, terbukti mampu memberikan fasilitas yang tidak kalah menarik dengan media lain yang membutuhkan biaya yang tinggi dalam menggunakannya. Bukan tidak mungkin, jika digunakan secara optimal, media sosial dapat menciptakan citra merek (brand Image) bagi UMK.

\section{c. Interaksi Secara Online Dengan Konsumen}

Komunikasi dapat menginformasikan dan membuat konsumen menyadari atas keberadaan produk yang kita tawarkan. Komunikasi merupakan strategi untuk membujuk konsumen agar mau membeli produk yang kita tawarkan. Oleh karena itu seorang pelaku usaha perlu menjaga komunikasi kepada konsumen baik berinteraksi secara langsung maupun berinteraksi secara online. Komunikasi merupakan bagian dari pelayanan, sebagaimana kita ketahui bahwa dalam berjual beli kita perlu menjaga dua hal terpenting yaitu kualitas dan pelayanan. Dengan menjaga komunikasi dengan konsumen, maka konsumen akan merasa nyaman dalam membeli produk kita. Mereka akan merasa terpenuhi keinginannya dengan pelayanan atau komunikasi yang baik yang kita berikan sehingga konsumen akan berlangganan membeli produk kita. media sosial berpotensi untuk membantu pelaku UMKM dalam memasarkan produknya. Melalui media sosial kita dapat berinteraksi secara online dengan konsumen. Sebagai pelaku UMK kita harus bisa menerima saran ataupun kritikan dari konsumen. Kita juga harus mampu memberikan tanggapan atau solusi yang tepat terhadap permasalahan yang muncul. Hal tersebut sama

instan hingga situs jejaring sosial yang menawarkan pengguna untuk berinteraksi, berhubungan, dan berkomunikasi satu sama lain (Purwana, 2017). 


\section{d. Pemanfaatan Pembiayaan Bank Umum Syariah Pada Pelaku UMK di Kecamatan Puuwatu Kota Kendari}

Pada penelitian ini pembiayaan bank umum syariah masih minim dimanfaatkan oleh pelaku UMK yang ada di Kecamatan Puuwatu Kota Kendari. Dari 10 sampel UMK hanya terdapat 2 UMK yang menggunakan perbankan syariah sebagai tempat penyimpanan dana usahanya. Penyebab dari kurangnya pelaku UMK di Kecamatan Puuwatu Kota Kendari menggunakan bank umum syariah dalam menyimpan dana usahanya adalah keuntungan dari penjualan produk tersebut digunakan dengan cara sistem perputaran. Sehingga keuntungan dari penjualan produk terus digunakan untuk menggaji karyawan, biaya operasional usaha, dan untuk meningkatkan volume produk yang lebih banyak dari sebelumnya. Selain itu hanya ada 1 UMK yang melakukan pembiayaan perbankan syariah yaitu UMK Durian Online. UMK Durian Online melakukan pembiayaan syariah pada Bank BRI Syariah berupa akad Mudharabah yaitu hubungan kerja sama antara dua atau lebih pihak dimana pemilik modal (shahibul mal) mempecayakan kepada pengelola (mudharib) dengan perjanjian di awal yang telah disepakati. Presentase bantuan modal usaha dari BRI Syariah yang diberikan kepada usaha Durian Online sebesar 30\% dan 70\% nya merupakan modal usaha pribadi.

\section{Kesimpulan}

Media sosial yang dominan digunakan oleh pelaku UMK di Kecamatan Puuwatu adalah media sosial facebook. Selain fiturnya yang sangat mudah digunakan oleh semua kalangan usia, facebook juga memiliki forum berupa grup jual beli yang memiliki pengikut 100 ribu bahkan 400 ribu lebih masyarakat. Sehingga mayoritas pelaku UMK di Kecamatan Puuwatu Kota Kendari lebih dominan menggunakan Facebook sebagai sarana pemasaran produk usahanya.

Media sosial telah memberikan kontribusi yang cukup besar bagi pelaku UMK di Kecamatan Puuwatu Kota Kendari. Dari penelitian ini hampir dari 10 sampel UMK mendapatkan presentase keuntungan yang lebih besar dari media sosial dibandingkan penjualan secara tradisional. Media sosial dapat meningkatkan penjualan produk, membangun kesadaran merek, dan memudahkan komunikasi secara online antara penjual dan pembeli.

Pembiayaan bank umum syariah masih minim dimanfaatkan oleh pelaku UMK yang ada di Kecamatan Puuwatu Kota Kendari. Selain itu mayoritas dari mereka tidak memanfaatkan bank umum syariah sebagai tempat penyimpanan modal usaha dikarenakan keuntungan dari penjualan produk 
digunakan dengan cara sistem perputaran. Sehingga keuntungan dari penjualan produk terus digunakan untuk menggaji karyawan, biaya operasional usaha, dan untuk meningkatkan volume produk yang lebih banyak dari sebelumnya. 


\section{References}

Agung, Muhammad, Dharmawan, Efektivitas Endorsement Non-Selebrity Dalam Membangun Citra Merek Produk Usaha Mikro Kecil Menengah (UMKM) Di Kota Makassar, (Skripsi Universitas Islam Negeri Alauddin Makassar, 2019)

Asnawi, Nur \& Asnan, Muhammad, Fanani, Pemasaran Syariah Teori, filosofi \&isu-isu kontemporer, (Depok: Rajawali Pers, 2017)

Ayodya, Wulan. "UMKM 4.0, (Strategi UMKM Memasuki Era Digital)”.(Jakarta: PT Elex Media Kompetindo, 2020)

Bahri, Syabbul, Hukum Promosi Produk Dalam Perspektif Hukum Islam, Jurnal Epistemé, Vol. 8, No. 1, Juni 2013

Chaffey, Dave. Digital Business and E-Commerce Management. Strategy, Implementation, and Practice

Danim, Sudarwan. Menjadi Peneliti Kualitatif. (Bandung: Pustaka Setia, 2002)

Dedi Purwana ES, dkk, "Pemanfaatan Digital Marketing Bagi Usaha Mikro, Kecil, dan Menengah (UMKM) di Kelurahan Malaka Sari, Duren Sawit”

Dwi, Bambang, Atmoko. Instagram Handbook, (Jakarta: Media Kita, 2012)

Dwi, Indah, Pratiwi. Penelitian Indah Dwi Pratiwi tahun 2019 dalam skripsi yang berjudul "Strategi Peningkatan Daya Saing Usaha Mikro Melalui Marketing Online Dalam Perspektif Ekonomi Islam (Studi Pada Pusat Layanan Usaha Terpadu dan Pelaku Industri Kerajinan Tapis di Bandar lampung), (Skripsi Universitas Islam Negeri Raden Intan Lampung, 2019)

Faisal, Afiah, Metode Penelitian Sosial, (Jakarta: Erlangga, 2001)

Gunawan Imam, Metode Penelitian Kualitatif, (Jakarta: Bumi Aksara 2013)

Hafsah, M.J. 2004. Upaya Pengembangan Usaha Kecil dan Menengah (UKM). Jurnal Infokop Nomor 25 Tahun XX

Iman, Daniel, K. dkk, "Pengaruh Pemasaran Melalui Media Sosial terhadap Kesadaran Konsumen pada Produk Internasional', Jurnal Administrasi Bisnis Universitas Brawijaya Malang, Vol.24 No. 1 Juli 2005

Jauhari, Jaidan. 2010. Upaya Pengembangan Usaha Kecil dan Menengah (UKM) Dengan Memanfaatkan ECommerce. Jurnal Sistem Informasi Fasilkom Universitas Sriwijaya Vol 2 No.1

Kaplan, Andreas, and Haenlein, Michael. "Users of The World, Unite! The Challenges and Opportunities of Social Media". Kelley School of Business, Business Horizon, Vol. 53, No. 1.2010,

Kuncoro, Mudrajad. 2008. Tujuh Tantangan UKM di Tengah Krisis Global. Harian Bisnis Indonesia 21 Oktober 2008

Moleong, Lexy J.Metodologi Penelitian Kualitatif (Bandung: PT Remaja Rosdakarya, 2002)

Morissan. 2007. Periklanan: Komunikasi Pemasaran Terpadu. Jakarta : Ramdina Prakarsa.

Muttaqin, Zainal, “Facebook Marketing Sebagai Komunikasi Pemasaran Modern”, Jurnal Sistem Informasi, Vol. 1 No. 2, Juli 2011

Nisrina M, Bisnis Online, Manfaat Sosial Media Dalam Meraup Uang, (Yogyakarta: Kobis, 2015)

Paramitha, Cindy, Rizal Putri. Analisis Faktor Pengaruh Promosi Berbasis Sosial Media terhadap Keputusan Pembelian Palanggan dalam Bidang Kuliner. Thesis. Semarang: fak. Ekonomi UNDIP

Pradiani, Theresia. 2017. Pengaruh Sistem Pemasaran Digital Marketing Terhadap Peningkatan Volume Penjualan Hasil Industri Rumahan. Jurnal Ilmiah Berbasis dan Ekonomi Asia (JIBEKA) Vol. 11 No. 2

Purwana, Dedi, E.S. dkk, “Pemanfaatan Digital Marketing Bagi Usaha Mikro, Kecil, dan Menengah (UMKM) di Kelurahan Malaka Sari, Duren Sawit". 
Rachmawati, Fitri. Penerapan Digital Marketing Sebagai Strategi Komunikasi Pemasaran Terpadu Produk Usaha Kecil Dan Menengah (UKM) Pahlawan Ekonomi Surabaya. (Skripsi Universitas Islam Negeri Sunan Ampel Surabaya, 2018)

Sanjaya, Ridwan dan Taringan, Josua. Creative Digital Marketing

Sarwono, Jonathan. Metode Penelitian Kuantitatif dan Kualitatif (Yogyakarta: Graha Ilmu, 2006)

Setiadi, Nugroho J.2003. Perilaku Konsumen: Konsep dan Implikasi untuk Strategi dan Penelitian Pemasaran. Jakarta: Prenada Media.

Slamet, Salim, Penerapan e-Commerce Sebagai Upaya Pengembangan Usaha Kecil dan Menengah yang Berdaya Saing Global (Studi Kasus pada Sentra Industri Keripik Tempe Sanan Kota Malang)”, (Skripsi Universitas Islam Negeri Maulana Malik Ibrahim, 2010)

Sugiono, Memahami Penelitian Kualitatif, (Bandung : Alphabeta), 2005

Supardi, Julian. 2009. Rancang Bangun Collaborative System Pemasaran Hotel Secara on-line Dengan Pendekatan Mediator based. Jurnal Sistem Informasi Fasilkom Unsri Vol 1 No 2

Trio, Mohamed, Febriyanto dan Arisandi, debbey, "Pemanfaatan Digital Marketing Bagi Usaha Mikro, Kecil, Dan Menengah Pada Era Masyarakat Ekonomi Asean", (Jurnal Nasional Universitas Universal, 2018), Vol 1 No.2

Utari, Monica, "Pengaruh Media Sosial Instagram Akun @Princessyahrini Terhadap Gaya Hidup Hedonis Para Followersnya”. Jurnal Ilmu Komunikasi FISIP, Vol.4 No.2, Oktober 2017

Yulianti, Analisis Strategi Promosi Melalui Pemanfaatan Media Sosial Instagram Dalam Meningkatkan Penjualan Produk Online Shop Ditinjau Dari Perspektif Ekonomi Islam (Studi Pada Miandsha Shop, Bandar Lampung), (Skripsi Universitas Islam Negeri Raden Intan Lampung, 2019)

Zarella, Dan. The Social Media Marketing Book. (Canada: O’Reilly Media, 2010) 